\title{
Xylem hydraulic efficiency versus vulnerability in seedlings of four contrasting Mediterranean tree species (Cedrus atlantica, Cupressus sempervirens, Pinus halepensis and Pinus nigra)
}

\author{
Fabienne Froux ${ }^{\mathrm{a}, \mathrm{b}}$, Roland Huc ${ }^{\mathrm{a}^{*}}$, Michel Ducrey ${ }^{\mathrm{a}}$ and Erwin Dreyer ${ }^{\mathrm{b}}$ \\ a INRA, Unité de Recherches Forestières Méditerranéennes, Avenue A. Vivaldi, 84000, Avignon, France \\ b UMR INRA-UHP, "Écologie et Écophysiologie Forestières”, 54280, Champenoux, France
}

(Received 5 November 2001; accepted 11 February 2002)

\begin{abstract}
We studied the xylem hydraulic traits and anatomy of four diverse Mediterranean conifers to determine how these species protect themselves against catastrophic xylem failure. Cedrus atlantica, Cupressus sempervirens, Pinus nigra and P. halepensis seedlings were grown for two years in pots in a greenhouse under well-watered conditions. Measurements were conducted in April and September. The vulnerability to cavitation was lower in April in the two pines and cedar whereas the conductivity was lower in the two pines and cypress. There were also large species differences in vulnerability to cavitation in September: loss of $50 \%$ conductivity occurred at $-2.8 \mathrm{MPa}$ in $P$. nigra, $-3.8 \mathrm{MPa}$ in $C$. atlantica, $-4.8 \mathrm{MPa}$ in C. sempervirens and $-4.9 \mathrm{MPa}$ in $P$. halepensis. Leaf specific hydraulic conductivity was much higher in Cupressus sempervirens and $P$. nigra than in Cedrus atlantica and $P$. halepensis. No trade-off between xylem safety (low vulnerability) and efficiency (high hydraulic conductivity) was found among the four species. Specific conductivity was directly related to "hydraulic mean" tracheid lumen diameter, while xylem vulnerability appeared to be independent of tracheid size.
\end{abstract}

xylem embolism / hydraulic conductivity /xylem anatomy / Mediterranean conifers

Résumé - Efficience hydraulique et vulnérabilité de plantules de quatre espèces de conifères méditerranéens (Cedrus atlantica, Cupressus sempervirens, Pinus halepensis et Pinus nigra). Nous avons étudié les caractéristiques hydrauliques et l'anatomie du xylème de quatre espèces de conifères méditerranéens afin de déterminer comment ces espèces se protègent contre un dysfonctionnement catastrophique du xylème. Des plants de Cedrus atlantica, Cupressus sempervirens, Pinus halepensis et $P$. nigra ont été cultivés en serre pendant deux ans en conditions d'alimentation en eau non limitante. Les mesures ont été effectuées en avril et septembre. La vulnérabilité à la cavitation a été plus faible en avril chez les deux pins et le cèdre tandis que la conductivité hydraulique a été plus faible chez les deux pins et le cyprès. D'importantes différences de vulnérabilité à la cavitation ont également été observées entre les espèces en septembre : la perte de $50 \%$ de conductivité est intervenue à $-2,8 \mathrm{MPa}$ chez $P$. nigra, $-3,8 \mathrm{MPa}$ chez $C$. atlantica, $-4,8 \mathrm{MPa}$ chez $C$. sempervirens et $-4,9 \mathrm{MPa}$ chez $P$. halepensis. La conductivité spécifique foliaire a été plus élevée chez $C$. sempervirens et $P$. nigra que chez $C$. atlantica et $P$. halepensis. Aucun compromis n'a été mis en évidence entre la protection du système conducteur (faible vulnérabilité à la cavitation) et l'efficacité de la circulation de la sève (forte conductivité hydraulique) entre les 4 espèces. La conductivité hydraulique spécifique est positivement corrélée avec le diamètre « hydraulique moyen » des lumières des trachéides alors que la vulnérabilité du xylème semble être indépendante de la taille des trachéides.

embolie / conductivité hydraulique / anatomie du xylème / conifères méditerranéens

* Correspondence and reprints

Tel.: +33 49013 59 50; fax: +33 49013 59 59; e-mail: Huc@avi-forets.avignon.inra.fr 


\section{INTRODUCTION}

The Mediterranean climate is characterized by a long dry summer. Drought can be severe where soils are shallow or coarse textured. Under such conditions, the xylem of trees may be subjected to very low water potentials that approach the dysfunction point where runaway embolism due to cavitation and air filling in the conduits reduces xylem conductivity [23]. The ecophysiological basis for drought tolerance in trees remains to a great extent unknown since the capacity to survive long-term water deficit is dependent on various physiological and morphological traits such as gas exchange control, osmotic adjustment and root to leaf area ratio adjustment. The implications of xylem hydraulic properties for drought tolerance have been proposed for several species $[1,5,11]$ but remain obscure for others.

Xylem vulnerability to water stress induced embolism is well documented in a wide range of species (see review by Tyree and Ewers [28]). Inter-specific differences in hydraulic properties are associated with habitat preference, as was observed in neotropical shrubs [5], in temperate broadleaved trees [11] and in conifer species [3].

The trade-off between safety (low vulnerability to water stress induced cavitation) and efficiency (large hydraulic conductivity), as hypothesized by Zimmermann [31], is a controversial subject and remains to be examined on species displaying diverse xylem characteristics and living under climates with a pronounced dry season.

Species adapted to the long dry Mediterranean summer should provide a good opportunity to study the tradeoff between efficiency and vulnerability and the effect of xylem anatomy on hydraulic properties. This research investigates xylem water transport and vulnerability in seedlings of four diverse tree species. We studied: (1) the variability of the hydraulic features with date of measurement; (2) the trade-off between safety (estimated from vulnerability to cavitation) and efficiency (estimated from hydraulic conductivity); (3) the relation between xylem anatomy and hydraulic properties; and (4) the relation of hydraulic characteristics to drought resistance. The hydraulic characteristics of seedlings of four Mediterranean conifer species (Cedrus atlantica, Cupressus sempervirens, Pinus halepensis and Pinus nigra) grown under controlled conditions were determined. Species were chosen according to their strategy of response to drought stress. In $P$. halepensis and $P$. nigra, daily minimum water potential $\left(\Psi_{\min }\right)$ never decreased below $-2.8 \mathrm{MPa}$ and $-1.5 \mathrm{MPa}$, respectively under severe drought $[2,6]$, demonstrating efficient stomatal closure.
In contrast, $C$. atlantica and $C$. sempervirens may display much lower xylem water potential [4]. For instance, levels of $\Psi_{\min }$ recorded in C. atlantica in natural stands reached $-4 \mathrm{MPa}$ [1]. Interestingly, P. nigra and C. atlantica are co-occurring species in Mediterranean mountains, while $C$. sempervirens and $P$. halepensis cooccur in low elevation forests under Mediterranean climate. Such differences in stomatal control of $\Psi_{\text {min }}$ could be due to different hydraulic properties.

\section{MATERIALS AND METHODS}

\subsection{Plant material}

Seeds from four Mediterranean conifers (Cedrus atlantica Manetti, Cupressus sempervirens L., Pinus halepensis Mill. and Pinus nigra Arn. ssp. nigricans Host. var. austriaca) were collected in natural populations in southern France near Avignon. C. atlantica was introduced to southern France from Algeria over 140 years ago. The plantations were very successful and natural regeneration is abundant. The other three species are native to the region.

Seedlings were grown in 0.4 liter plastic containers in the spring of 1998 in the Les Milles nursery, near Aix-enProvence, France. One half of the seedlings were transplanted at the end of March 1999 to 7 liter containers filled with a mixture of sand/peat/forest soil horizon A1 collected near Avignon (1/2/3, v/v/v). The pots were watered once or twice a week depending on the weather. A liquid fertilizer (Fertiligène NPK 9/9/9) was added once a week to the irrigation water (1\%). Plants were grown in a greenhouse in Avignon, France, under $85 \%$ of full sunlight. Temperature minima in winter were kept above $2{ }^{\circ} \mathrm{C}$ by heating and during the summer the maxima were maintained between $25^{\circ} \mathrm{C}$ and $32{ }^{\circ} \mathrm{C}$ by ventilation and cooling. The cypress trees produced a 50:50 mix of two forms: horizontalis (plagiotropic) and fastigiata (orthotropic).

\subsection{Hydraulic conductivity}

Two series of measurements were carried out during 1999, one in April before bud break on 1998 twigs of non-transplanted plants, and a second one during September on current year (1999) twigs on seedlings transplanted to larger pots in March. Eight seedlings of $P$. halepensis, $C$. atlantica and $P$. nigra and six seedlings 
of each form (horizontalis and fastigiata) of C. sempervirens were transported to the laboratory where predawn needle water potential was measured on terminal twigs with a Scholander pressure chamber. Seedling tops were severed from the roots just above the root collar and cut again under water to remove embolized tracheids close to the cut end. Three segments were cut underwater from the most recent year's growth: one 10-cm-long segment for determination of vulnerability curves and two 2-cm-long segments on each side and adjacent to the long segment for hydraulic conductivity measurements. All segments were debarked underwater. Projected area $\left(L_{\mathrm{a}}\right)$ of all needles supplied with water by the segment was measured using a planimeter (System DIAS II of Delta-T-Device).

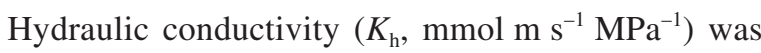
measured according to the method described by Sperry and Tyree [23]. Segments were perfused with a degassed dilute solution of water and $\mathrm{HCl}(\mathrm{pH}=2)$ filtered with a $0.1 \mu \mathrm{m}$ filter with an applied pressure of $3.5 \mathrm{kPa}$. The following hydraulic properties were determined for each segment:

(i) leaf specific conductivity $\left(K_{\mathrm{l}}, \mathrm{mmol} \mathrm{m} \mathrm{m}^{-1} \mathrm{~s}^{-1} \mathrm{MPa}^{-1}\right)$ :

$$
K_{1}=K_{\mathrm{h}} / L_{\mathrm{a}} ;
$$

(ii) specific conductivity $\left(K_{\mathrm{s}}, \mathrm{mol} \mathrm{m}^{-1} \mathrm{~s}^{-1} \mathrm{MPa}^{-1}\right)$ :

$$
K_{\mathrm{s}}=K_{\mathrm{h}} / S_{\mathrm{a}}
$$

where $S_{\mathrm{a}}$ is the sapwood transverse area of the segment (excluding the central pith).

(iii) Huber value $\left(H V, \mathrm{~m}^{2} \mathrm{~m}^{-2}\right)$ as:

$$
H V=S_{\mathrm{a}} / L_{\mathrm{a}} .
$$

\subsection{Xylem vulnerability to cavitation}

Cavitation was induced using the air injection method [22]. Segments severed from the main shoot were inserted into a double-ended pressure chamber with both ends protruding to allow direct measurements of $K_{\mathrm{h}}$. Samples were not notched because air entry was assured by abundant needle scares. The segments were subjected to an air pressure of $0.05 \mathrm{MPa}$ during conductivity measurements to prevent lateral leakage of solution from the segment through needle scars. Native embolism was not measured because flushing at high pressure did not increase $K_{\mathrm{h}}$. We believed native embolism was very low because the plants were always well watered. Hydraulic conductivity measured before induction of cavitations was taken to be the maximum conductivity $\left(K_{\max }\right)$. Cavitations were induced by 10 minutes pressurizations at pressures ranging from 0.8 to $8 \mathrm{MPa}$ in 10 steps at regular intervals. Each pressurization was followed by a $30 \mathrm{~min}-$ utes relaxation at atmospheric pressure and by measurement of $K_{\mathrm{h}}$. Percent loss of conductivity (PLC) was estimated as:

$$
P L C=100 \times\left(K_{\max }-K_{\mathrm{h}}\right) / K_{\max } .
$$

\subsection{Anatomical characteristics}

Samples used during September for xylem vulnerability assessment were preserved to FAA solution (formaldehyde $10 \%$, acetic acid 5\%, alcohol $35 \%$ in water). Two $1-\mathrm{cm}$ long pieces of each sample were shredded and mixed for 6 hours with Jeffrey's solution (10\% chromic acid $+10 \%$ nitric acid in distilled water) in separate vials as described by Hargrave et al. [7]. After several rinsings with distilled water the length of 60 macerated fibers in each sample was measured at $25 \mathrm{X}$ with a light microscope.

Four cross-sections were cut with a razor blade from each stem segment used for conductivity measurement and stained with $0.5 \%$ safranin. An image analysis system (NIH-Image Software, Scion Corp.) was used to determine lumen cross-sectional area of all tracheids $(\mathrm{n} \approx 200)$ by $3-\mu \mathrm{m}$ lumen diameter class from color slides taken with a light microscope at 100X. The hydraulic conductivity per lumen diameter class and the total hydraulic conductivity of the sample were calculated using the Hagen-Poiseuille equation [30]. "Hydraulic mean" diameter $(D)$ for each segment was calculated from measured lumen diameter $(d)$, using 3- $\mu$ m lumen diameter classes, as:

$$
D=\sum d^{5} / \sum d^{4}[12,21] .
$$

\subsection{Statistical analysis}

Analysis of variance was used to determine the significance of species and date effect on hydraulic and anatomical properties. The significance of differences between means was assessed with the Duncan test $(P<0.05$, GLM procedure, SAS, Statistical Analysis System, Cary, NC).

The data for the relation of PLC versus applied pressure $(\Psi)$ were fitted to a logistic function [14]:

$$
P L C=100 /\left(1+\exp \left(a\left(\Psi-\Psi_{\text {PLC50 }}\right)\right)\right),
$$

using the SAS non linear regression procedure (NLIN). The maximum slope of the function occurs at $50 \%$ loss of conductivity and is given by " $a$ ". The xylem water 
potential inducing $50 \%$ loss of conductivity is given by $\Psi_{\mathrm{PLC5}}$. Xylem potential inducing $10 \%$ loss of conductivity was also calculated as $\Psi_{\mathrm{PLC1} 10}$. Data for each segment were fitted to the logistic function and the resulting parameters were used to calculate a mean value and a standard error of $\Psi_{\mathrm{PLC} 50}, \Psi_{\mathrm{PLC1} 10}$ and $a$ by species and date.

\section{RESULTS}

\subsection{Hydraulic conductivity}

The predawn xylem water potential showed the seedlings were not under water stress at the time of measurement of hydraulic properties (values ranged from -0.5 to $-0.3 \mathrm{MPa}$ ). Data for the two growth forms of C. sempervirens ("horizontalis" and "fastigiata") were pooled for analysis after it was determine no differences existed between them for any of the hydraulic and anatomical characteristics. A species effect on the different hydraulic parameters was found when analyzing both measurement dates together $(P<0.001)$. Species ranking was found to be different between dates; therefore, the analysis of species differences was conducted separately by date and the analysis of differences between dates was done separately by species. The effect of measurement date appeared to be an increase in conductivity and $H V$ from April to September (table I). The increase occurred in $K_{\mathrm{s}}$ for Pinus halepensis and C. sempervirens, in $K_{1}$ for all species except $C$. atlantica and in $H V$ for $P$. nigra. There was a tendency for $P$. halepensis to have the lowest values and $C$. sempervirens to have the highest values for all hydraulic conductivity parameters for both dates.

\subsection{Vulnerability to cavitation}

There was a tendency for the current stem to become more vulnerable to cavitation from April to September (smaller $\Psi_{\mathrm{PLC50}}, P$. nigra, $P$. halepensis and C. atlantica) and for cavitation to occur more rapidly (smaller $\Psi_{\text {PLC50 }}$ $\Psi_{\mathrm{PLC1} 10}$, C. atlantica and C. sempervirens) (table II and figure 1). There did not appear to be a consistent effect of date on $\Psi_{\mathrm{PLC} 10}$, but $P$. halepensis displayed a change in this value from -3.91 MPa in April to -1.38 MPa in September. It appeared that, regardless of the date, $P$. nigra was the most and $P$. halepensis the least vulnerable to cavitation. In contrast, cavitations propagated most rapidly in $C$. sempervirens (highest " $a$ " and smallest $\Psi_{\mathrm{PLC50}}$
- $\left.\Psi_{\mathrm{PLC10}}\right)$ in April and September and least rapidly in $P$. halepensis in September (largest $\Psi_{\mathrm{PLC} 50}-\Psi_{\mathrm{PLC} 10}$ ).

\subsection{Xylem anatomy}

The range of tracheid lengths was similar among species $(0.5$ to $2.5 \mathrm{~mm})$ but mean length was larger in C. atlantica and P. halepensis than in P. nigra and C. sempervirens (table III). Tracheids longer than $1.25 \mathrm{~mm}$ accounted for only $16 \%$ of the total in $P$. nigra and $C$. sempervirens while they amounted to 37 and $51 \%$ in $P$. halepensis and C. atlantica. The largest diameter tracheid lumens were found in $C$. sempervirens (figure 2 and table III). The large-diameter tracheid lumens (over $12 \mu \mathrm{m}$ ) represented $51 \%$ of the cumulative cross-sectional area of all tracheid lumens in the sapwood and contributed $77 \%$ of the theoretical conductivity in C. sempervirens. The three other species displayed smaller tracheid lumens with a mean diameter close to $10 \mu \mathrm{m}$. The large-diameter tracheid lumens accounted for 41,32 and $21 \%$ of the calculated conductivity in P. nigra, P. halepensis and C. atlantica, respectively. The ratio measured/calculated conductivity was greatest in P. halepensis and C. sempervirens (table III).

\section{DISCUSSION}

The findings of the research reported here for two different dates confirmed the expected variability in hydraulic properties of seedlings of Mediterranean trees. The study found no evidence of a relation between hydraulic efficiency and safety. There was strong support for a close relation between some anatomical characteristics of the xylem and hydraulic properties. In addition, some aspects of drought resistance were related to the hydraulic properties. However, we have to take into account the limitations of the study since we used potted seedlings with a restricted root system which did not represent natural conditions of these species. Plants experienced different root-to-soil interaction between the two sets of measurements which may have influenced their hydraulic architecture. Moreover, the root system may have been affected in a different manner by repotting depending on the species, resulting in different xylem anatomy. 
Table I. Specific conductivity $\left(K_{\mathrm{s}}, \mathrm{mol} \mathrm{m}^{-1} \mathrm{~s}^{-1} \mathrm{MPa}^{-1}\right)$, leaf specific conductivity $\left(K_{\mathrm{l}}, \mathrm{mmol} \mathrm{m}^{-1} \mathrm{~s}^{-1} \mathrm{MPa}^{-1}\right)$, and $\mathrm{Huber}$ value $H \mathrm{v}$ $\left(10^{5} \mathrm{~m}^{2} \mathrm{~m}^{-2}\right)$ recorded in the main shoot of seedlings of four Mediterranean conifers during April and September. Mean and standard error of the mean (SEM) of 6 to 22 replicates. S and NS indicate significant and non-significant date effect $(P=0.05)$. Different letters denote significant differences among species for a given parameter at $P=0.05$ (Duncan test).

\begin{tabular}{|c|c|c|c|c|}
\hline & Species & April Mean (SEM) & September Mean (SEM) & Date effect \\
\hline \multirow[t]{4}{*}{$K_{\mathrm{s}}$} & Pinus nigra & $14.53(1.23)^{\mathrm{a}}$ & $17.61(2.47)^{\mathrm{b}}$ & NS \\
\hline & Pinus halepensis & $10.11(0.76)^{b}$ & $15.88(1.35)^{\mathrm{b}}$ & $S$ \\
\hline & Cedrus atlantica & $16.02(2.09)^{\mathrm{a}}$ & $16.26(1.62)^{\mathrm{b}}$ & NS \\
\hline & Cupressus sempervirens & $15.25(1.06)^{\mathrm{a}}$ & $30.76(1.78)^{\mathrm{a}}$ & $S$ \\
\hline \multirow[t]{4}{*}{$K_{1}$} & Pinus nigra & $10.11(1.02)^{\mathrm{b}}$ & $28.05(6.95)^{a}$ & $S$ \\
\hline & Pinus halepensis & $4.39(0.36)^{\mathrm{c}}$ & $7.11(0.47)^{\mathrm{b}}$ & S \\
\hline & Cedrus atlantica & $12.53(1.50)^{a b}$ & $11.09(1.68)^{\mathrm{b}}$ & NS \\
\hline & Cupressus sempervirens & $14.92(1.12)^{\mathrm{a}}$ & $33.09(2.64)^{\mathrm{a}}$ & S \\
\hline \multirow[t]{4}{*}{$H \mathrm{v}$} & Pinus nigra & $61.31(3.55)^{\mathrm{c}}$ & $156.48(35.92)^{\mathrm{a}}$ & $S$ \\
\hline & Pinus halepensis & $40.86(2.13)^{d}$ & $46.54(5.53)^{\mathrm{c}}$ & NS \\
\hline & Cedrus atlantica & $76.17(1.87)^{\mathrm{b}}$ & $71.56(6.57)^{b c}$ & NS \\
\hline & Cupressus sempervirens & $93.55(4.19)^{\mathrm{a}}$ & $103.42(6.86)^{\mathrm{b}}$ & NS \\
\hline
\end{tabular}

Table II. Parameters calculated from PLC curves for four Mediterranean conifer species. $\Psi_{\mathrm{PLC} 10}, \Psi_{\mathrm{PLC} 50}$ (xylem water potential at $10 \%$ and $50 \%$ loss of conductivity, respectively) and " $a$ " (form parameter of the curves). Values were estimated using the SAS NLIN procedure from data on individual twig samples. Mean and standard error of the mean (SEM) of 6 to 12 replicates. Means in a column with the same letter are not significantly different among species at $P=0.05$ (Duncan test). Significance of date effect is shown as $\mathrm{S}$ (significant) or NS (non significant) $(P=0.05$, Duncan test).

\begin{tabular}{|c|c|c|c|c|}
\hline & Species & $\begin{array}{c}\text { April } \\
\text { Mean (SEM) }\end{array}$ & $\begin{array}{c}\text { September } \\
\text { Mean (SEM) }\end{array}$ & $\begin{array}{l}\text { Date } \\
\text { effect }\end{array}$ \\
\hline \multirow[t]{4}{*}{$\Psi_{\mathrm{PLC} 10}$} & Pinus nigra & $-1.78(0.29)^{b}$ & $-1.55(0.23)^{\mathrm{b}}$ & NS \\
\hline & Pinus halepensis & $-3.91(0.48)^{\mathrm{a}}$ & $-1.38(0.85)^{\mathrm{b}}$ & S \\
\hline & Cedrus atlantica & $-1.41(0.87)^{b}$ & $-2.04(0.52)^{b}$ & NS \\
\hline & Cupressus sempervirens & $-3.45(0.83)^{\mathrm{ab}}$ & $-4.25(0.24)^{\mathrm{a}}$ & NS \\
\hline \multirow[t]{4}{*}{$\Psi_{\text {PLC50 }}$} & Pinus nigra & $-3.08(0.25)^{\mathrm{c}}$ & $-2.76(0.12)^{\mathrm{c}}$ & S \\
\hline & Pinus halepensis & $-5.97(0.22)^{\mathrm{a}}$ & $-4.87(0.64)^{\mathrm{a}}$ & $S$ \\
\hline & Cedrus atlantica & $-5.08(0.30)^{\mathrm{ab}}$ & $-3.81(0.18)^{b}$ & S \\
\hline & Cupressus sempervirens & $-4.41(0.72)^{b c}$ & $-4.78(0.20)^{\mathrm{a}}$ & NS \\
\hline \multirow[t]{4}{*}{$\Psi_{\mathrm{PLC} 50}-\Psi_{\mathrm{PLC} 10}$} & Pinus nigra & $-1.30(0.19)^{\mathrm{b}}$ & $-1.21(0.28)^{b c}$ & NS \\
\hline & Pinus halepensis & $-2.06(0.32)^{b}$ & $-3.49(0.62)^{\mathrm{a}}$ & NS \\
\hline & Cedrus atlantica & $-3.67(0.65)^{\mathrm{a}}$ & $-1.77(0.47)^{\mathrm{b}}$ & $S$ \\
\hline & Cupressus sempervirens & $-0.97(0.24)^{b}$ & $-0.53(0.06)^{\mathrm{c}}$ & S \\
\hline \multirow[t]{4}{*}{$a$} & Pinus nigra & $1.89(0.28)^{b}$ & $2.21(0.31)^{\mathrm{b}}$ & NS \\
\hline & Pinus halepensis & $1.31(0.23)^{\mathrm{b}}$ & $0.77(0.11)^{\mathrm{b}}$ & NS \\
\hline & Cedrus atlantica & $0.74(1.13)^{b}$ & $2.44(0.88)^{\mathrm{b}}$ & NS \\
\hline & Cupressus sempervirens & $3.06(0.61)^{\mathrm{a}}$ & $4.92(0.74)^{\mathrm{a}}$ & NS \\
\hline
\end{tabular}


Table III. Mean tracheid length $(\mathrm{mm})$, mean lumen diameter $(\mu \mathrm{m})$, contribution of tracheids with lumens larger than $12 \mu \mathrm{m}$ in diameter to total sapwood area and estimated total conductivity, and ratio between measured and estimated conductivity in seedlings of four Mediterranean conifer species during September. Mean and standard error of the mean (SEM). Means in a column with the same letter are not significantly different.

\begin{tabular}{|c|c|c|c|c|c|}
\hline \multirow[t]{2}{*}{ Species } & \multirow{2}{*}{$\begin{array}{l}\text { Mean tracheid } \\
\text { length } \\
(\mathrm{mm})\end{array}$} & \multirow{2}{*}{$\begin{array}{l}\text { Mean tracheid } \\
\text { lumen diameter } \\
(\mu \mathrm{m})\end{array}$} & \multicolumn{2}{|c|}{$\begin{array}{l}\text { Contribution of tracheid with a lumen } \\
\text { diameter }>12 \mu \mathrm{m} \text { to }\end{array}$} & \multirow{2}{*}{$\begin{array}{c}\text { Ratio measured/ } \\
\text { estimated } \\
\text { conductivity }\end{array}$} \\
\hline & & & $\begin{array}{l}\text { total sapwood trans- } \\
\text { verse area }(\%)\end{array}$ & $\begin{array}{l}\text { estimated total } \\
\text { conductivity }(\%)\end{array}$ & \\
\hline Pinus nigra & $1.02(0.09)^{\mathrm{c}}$ & $10.4(1.08)^{b}$ & $14.9(2.9)^{b}$ & 47.41 & $0.34(0.02)^{a}$ \\
\hline Pinus halepensis & $1.26(0.28)^{a b}$ & $10.2(0.14)^{b}$ & $8.35(2.19)^{b}$ & 31.85 & $0.50(0.04)^{b}$ \\
\hline Cedrus atlantica & $1.33(0.13)^{\mathrm{a}}$ & $9.0(1.4)^{b}$ & $3.83(3.52)^{b}$ & 20.92 & $0.33(0.12)^{a b}$ \\
\hline Cupressus sempervirens & $1.06(0.09)^{b c}$ & $13.5(1.3)^{\mathrm{a}}$ & $51.2(18.7)^{\mathrm{a}}$ & 76.7 & $0.45(0.07)^{\mathrm{b}}$ \\
\hline
\end{tabular}

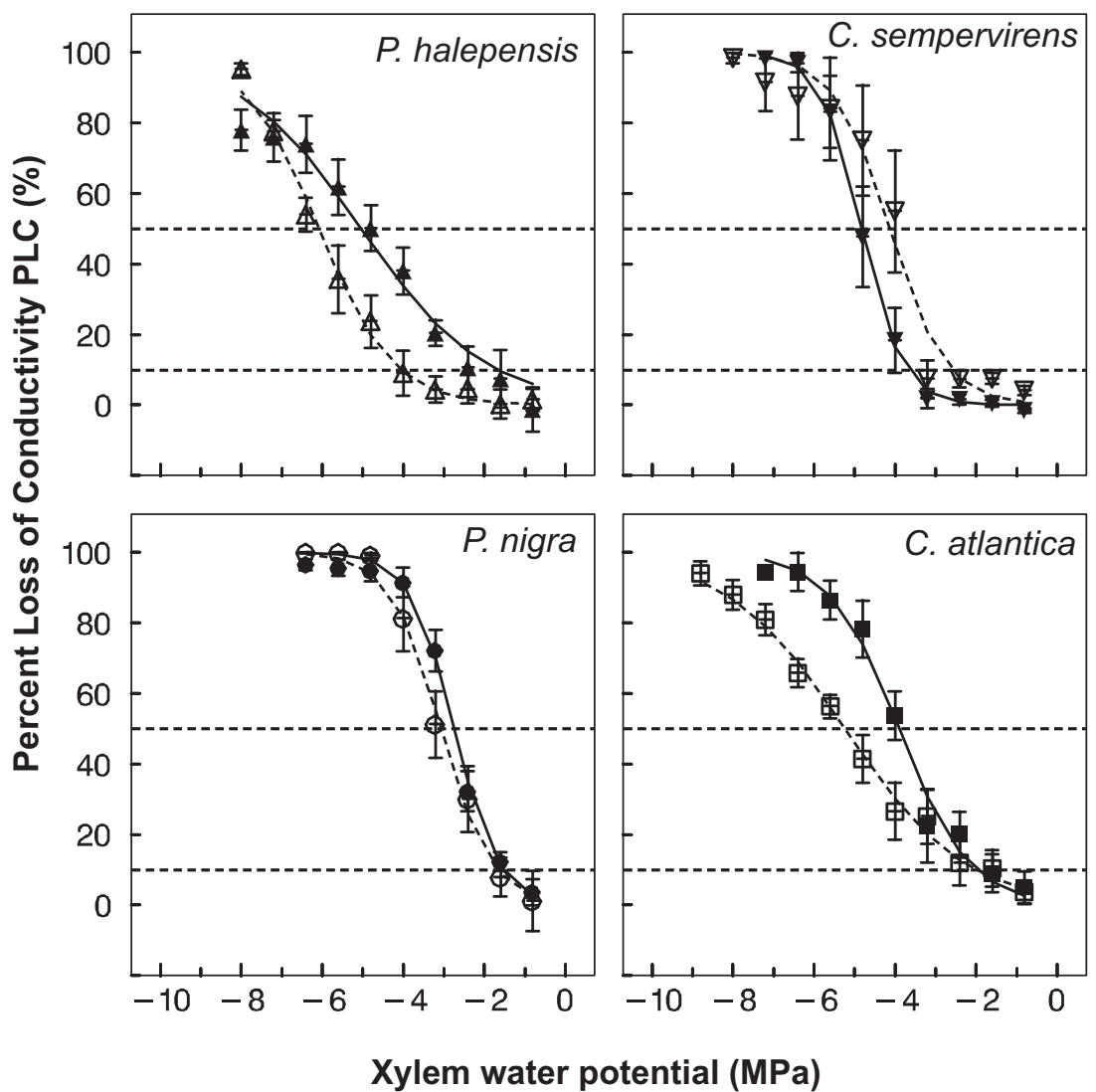

Figure 1. Vulnerability curves in seedlings of the four Mediterranean conifer species obtained during April (dashed line) and September (solid line) by pressurization of twigs. Vertical bars represent the standard error of the mean of 6 to 12 replications. Dotted horizontal lines represent the $10 \%$ and $50 \%$ loss of conductivity.

\subsection{Variation with the date of measurement}

The terminal stems from April had both earlywood and latewood produced the previous year and the terminal stems from September had essentially only earlywood from the current year. This was due to active cambial growth observed late in summer in greenhouse conditions. The presence of latewood in the April stems could have caused the differences in conductivity observed between the two dates of measurement. Lumen diameter is much smaller in latewood making it less efficient for conducting water $[9,31]$. In addition, in 


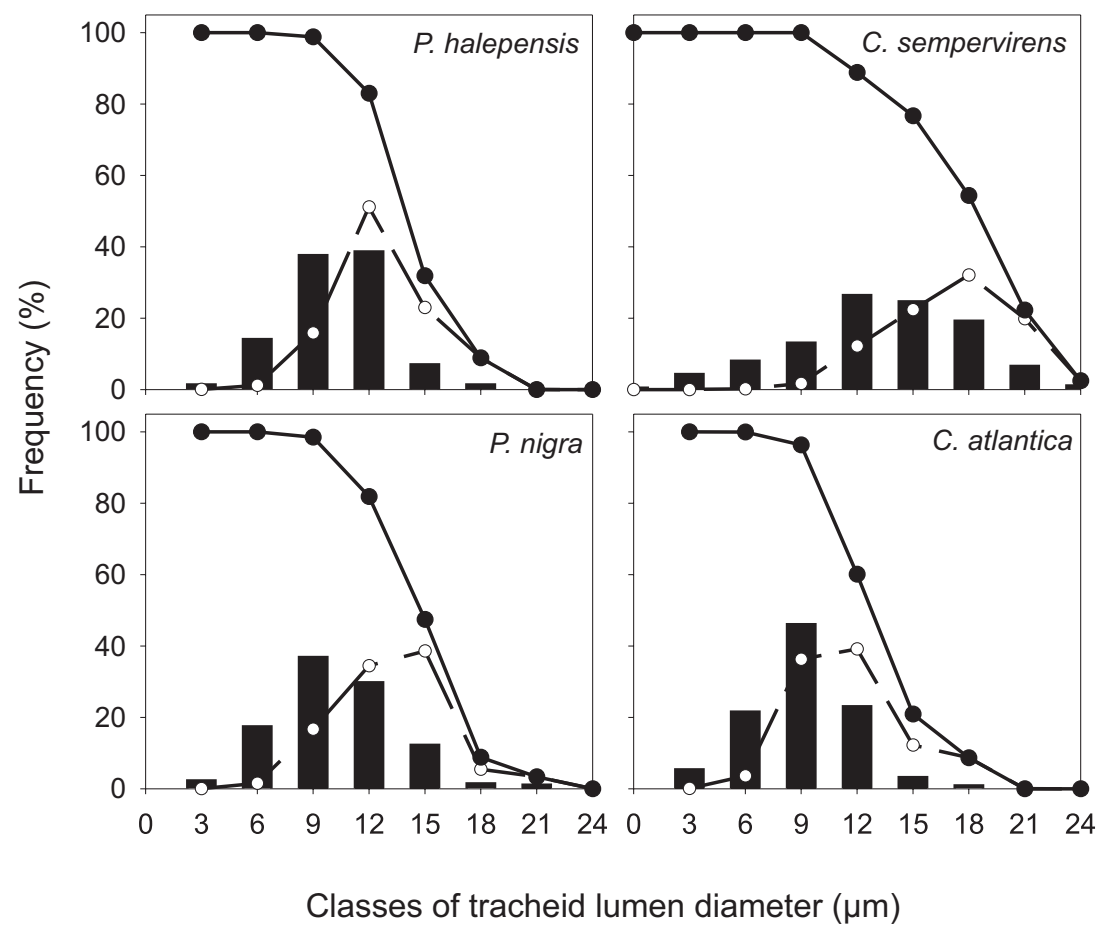

Figure 2. Frequency distribution of lumen cross-sectional area (bars), percent of total calculated conductivity (dashed line) and cumulative percent of total calculated conductivity beginning with large diameters and progressing toward small diameters by $3 \mu \mathrm{m}$ lumen diameter class (solid line) in seedlings of four Mediterranean conifers. coniferous species membrane pores of latewood have a more rigid structure than earlywood [15]. As a consequence, larger pressure drops would be necessary to induce air seeding and cavitation in latewood than in earlywood. This is consistent with our results as $P$. halepensis, $P$. nigra and $C$. atlantica were less vulnerable during April than during September.

\subsection{Hydraulic conductivity and tracheid anatomy}

The highest specific conductivity was recorded on the species with the largest lumen diameters (C. sempervirens) and a relationship was detected between measured hydraulic conductivity and "hydraulic mean" lumen diameter (figure 4) as expected from the Hagen-Poiseuille law [21, 28, 31]. Measured conductivity was 30 to 50 percent of calculated conductivity. This discrepancy could be due to: (1) the occurrence of naturally embolized tracheids [7] and (2) xylem conduits not functioning like ideal conduits. Native embolism was probably very low because the seedlings were always well watered. This could not be verified using flushing, due to irreversible displacement of torus in the pit.
Staining of xylem shows low native embolism $(<5 \%)$ and did not reveal differences between species (data not shown). The flow of water through xylem of conifers, which have small conducting units interconnected by pit openings, is essentially through these small pit pores. Thus, the number of connections between tracheids is assumed to determine the water flow conductance [19]. This may explain large differences between measured and theoretical values.

\subsection{Efficiency vs. safety}

A significant question for plant ecology is whether the efficient transport of water associated with large tracheids and pores may be less safe for water transport due to increased vulnerability to cavitation as suggested by physical models [31]. The results of our study showed large differences in hydraulic conductivity for Mediterranean conifers whether the basis was leaf area or crosssectional area. The differences between the most and least conductive ranged from 1.5 to 2 fold for $K_{\mathrm{s}}$ and 3 to 4 fold for $K_{1}$. The study also showed a large range of vulnerabilities to embolism with $\Psi_{\text {PLC50 }}$ ranging from 
$-2.76 \mathrm{MPa}$ in $P$. nigra to $-4.87 \mathrm{MPa}$ in $P$. halepensis in September. This wide range of efficiency and safety should provide a good test of the relation between these two traits (figure 3). In fact, our results did not show any trade-off between efficiency and safety.

A number of results from earlier work were consistent in regard to a trade-off between efficiency and safety. A trade-off was found when two Mediterranean oaks (Quercus ilex and Q. pubescens) were compared [26]. $Q$. ilex displayed both lower conductivity and lower vulnerability than $Q$. pubescens. A trade-off was also found in the Sonoran desert vegetation [17], in Mediterranean sclerophyllous trees [18] and in Pinaceae of the Pacific Northern [16]. The chaparral shrub species Malosma laurina had a larger water transport efficiency associated with a higher susceptibility to embolism compared to Heteromeles arbutifolia [8]. Meanwhile no such tradeoff was found among woody species in northern Utah and interior Alaska [25] and for subspecies of Artemisia tridentata [10]. Brodribb and Hill [3] have found no evidence of trade-off when comparing $K_{\mathrm{s}}$ and $K_{1}$ to xylem vulnerability in a sub-sample of four conifer species. No significant correlation was found by Tyree et al. [30] between $\Psi_{\mathrm{PLC5} 0}$ and volume or surface area of conducting units from a review of 13 conifers. There is also no

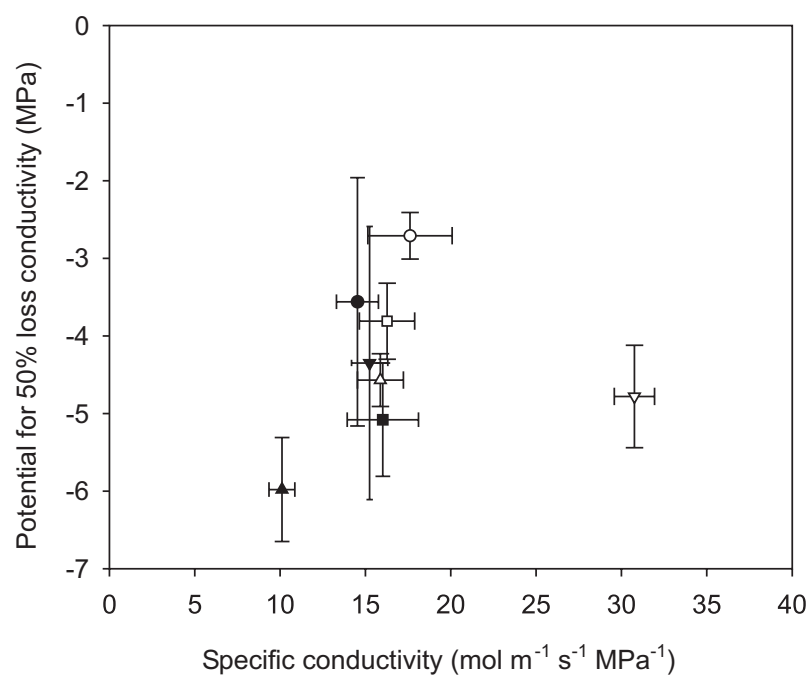

Figure 3. Relationship between xylem water potential inducing $50 \%$ loss of conductivity ( $\Psi_{\text {PLC50 }}$ ) and specific conductivity $\left(K_{\mathrm{s}}\right)$ in Pinus halepensis (triangle up), Cupressus sempervirens (triangle down), Pinus nigra (circle) and Cedrus atlantica (square) during April (open symbols) and September (closed symbols). Vertical and horizontal error bars are the standard error of the mean for $\Psi_{\mathrm{PLC50}}$ and $K_{\mathrm{s}}$ respectively. evidence of trade-off when analyzing variability among ecotypes. For instance, Pinus ponderosa showed larger conductivity in the dry site sources than mesic sources and no differences in vulnerability to cavitation [13]. A study of geographical variation in hydraulic characteristics of $P$. halepensis found no differences in $K_{\mathrm{s}}$ when trees were supplied with adequate water, but, when subjected to soil drought, xeric provenances were less vulnerable to embolism compared to mesic provenances [27].

Our data from interspecific comparisons revealed no clear relationship between vulnerability to embolism $\left(\Psi_{\mathrm{PLC5} 5}\right)$ and xylem anatomy (figure 4$)$. Large-diameter tracheids may have a greater vulnerability to embolism due to an increase in the number of large pores in pit membranes [7]. Accordingly, cypress should have shown the greatest vulnerability but it did not (tables $I$ and $I I I$ ). Other aspects of tracheid and pit anatomy may be important. In fact, it has been suggested that pit membrane flexibility due to hemicellulose fibers explains differences of vulnerability among species [24]. It appears the relation among hydraulic efficiency, safety and tracheid size is complex and requires further study.

Conifer xylem is characterized by a high level of redundancy in its conducting system due to the large

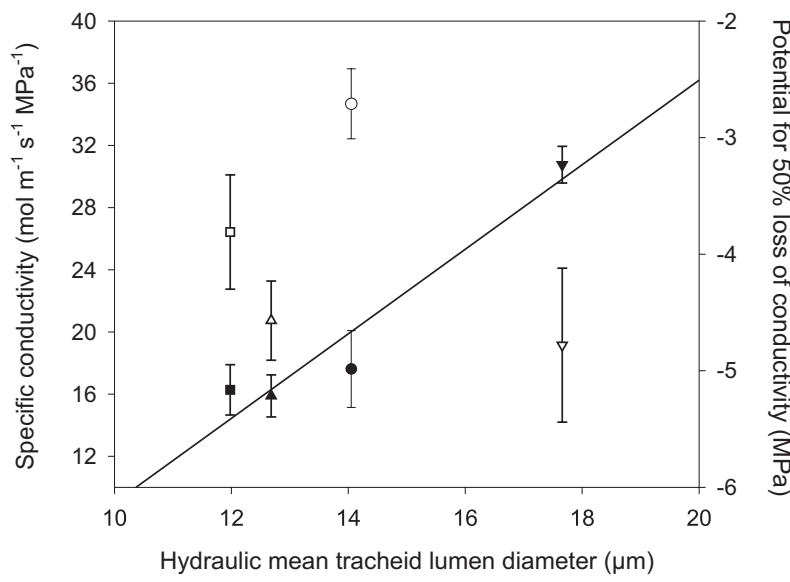

Figure 4. Relationship between "hydraulic mean" tracheid lumen diameter and specific hydraulic conductivity (closed symbols) or xylem water potential inducing $50 \%$ loss of conductivity (open symbols) in Pinus halepensis (triangle up), Cupressus sempervirens (triangle down), Pinus nigra (circle) and Cedrus atlantica (square). The line is the linear regression of specific conductivity on "hydraulic mean" tracheid lumen diameter $(r=0.863)$. Error bars are the standard error of the mean for $K_{\mathrm{s}}$ and $\Psi_{\mathrm{PLC50}}$. 
number of small tracheid units and the walls separating them $[24,31]$. This characteristic could promote the late start (low water potential) and slow propagation of embolisms. The results of our study provided some support for this relation between structure and function, as the species with the largest tracheids, C. sempervirens, showed the most rapid propagation of embolisms (small $\Psi_{\text {PLC50 }}-\Psi_{\text {PLC10 }}$, tables II and III). Interestingly, embolisms began very late in C. sempervirens (low $\Psi_{\mathrm{PLC1} 10}$ ). C. atlantica had the largest amount of small tracheids and a rather slow propagation of embolisms, but embolisms began rather early in this species.

\subsection{Hydraulic characteristics and drought tolerance}

The differences in the two major hydraulic properties, $\Psi_{\text {PLC50 }}$ and $K_{1}$, among the four conifer species might be indicative of differences in resistance to drought. The capacity to resist cavitation is often considered to be related to drought tolerance [4]. Our results suggested a ranking of species based on $\Psi_{\text {PLC50 }}$ from the most drought tolerant $P$. halepensis and $C$. sempervirens to the relatively less tolerant $C$. atlantica to the least tolerant $P$. nigra (table II). A study of several Mediterranean provenances of Cedrus libani and C. atlantica (Ladjal 2000, unpublished data) showed values of $\Psi_{\text {PLC50 }}$ from $-5 \mathrm{MPa}$ to -7 MPa. Broadleaved Mediterranean species have been found to show a comparable range of vulnerability [29].

During the Mediterranean summer, high evaporative demand leads to high transpiration and an increase in xylem tension. A large hydraulic conductivity helps to support high transpiration and may be beneficial as long as it does not promoted cavitation due to development of very low xylem water potentials [13]. Cavitation is prevented when stomatal closure occurs before the threshold water potential of vulnerability [20]. Earlier studies of conifers found a range of $K_{\mathrm{s}}$ and $K_{\mathrm{l}}$ similar to that of the current study [28]. Species with smaller $K_{1}$ and $K_{\mathrm{s}}$ (P. halepensis and C. atlantica) may be inclined to develop low xylem water potential. To prevent cavitation they may have more effective stomatal control or low vulnerability to cavitation. Data from our laboratory (Froux 2001, unpublished data) confirm that C. sempervirens and $P$. nigra which have larger $K_{\mathrm{l}}$ and $K_{\mathrm{s}}$ also have transpiration rates 1.6 times higher than $P$. halepensis and C. atlantica when xylem water potential is near $0.6 \mathrm{MPa}$.

\section{CONCLUSIONS}

The major conclusions are that there is a wide range of xylem anatomical and hydraulic properties in Mediterranean conifers that are consistent with and help explain the relative level of drought tolerance. The results suggest that drought tolerant species may have xylem hydraulic properties that are capable of sustaining high transpiration without development of lethal xylem tensions (high $K_{\mathrm{s}}$ and $K_{\mathrm{l}}$, and low $\Psi_{\text {PLC50 }}$ [13] as in C. sempervirens). Even P. halepensis which had relatively low xylem conductivity was protected from embolisms by very low vulnerability. In contrast the drought susceptible $P$. nigra from moist sites had rather high conductivity and low resistance to embolism. Important date effects was observed on conductivity that can be explained by changes in the amount of latewood. Anatomical traits like tracheid lumen diameter was directly related to conductivity and inversely related to the speed of propagation of embolisms. Further study of the relation of anatomical traits to hydraulic properties is necessary to explain why large tracheids can be associated with low vulnerability.

Acknowledgments: Fabienne Froux was supported by a Ph. D. grant of the French Ministry of Education. The technical assistance of Didier Betored and Arnaud Jouineau is gratefully acknowledged. We thank Dr Gilles Vercambre for his help in anatomical analysis, Dr Hervé Cochard for his critical remarks on a first draft. Special thanks are due to Dr Stephen Hallgren for helpful discussion and English review of the manuscript.

\section{REFERENCES}

[1] Aussenac G., Valette J.C., Comportement hydrique estival de Cedrus atlantica Manetti, Quercus ilex et Quercus pubescens Willd et de divers pins du Mont Ventoux, Ann. Sci. For. 39 (1982) 41-62.

[2] Borghetti M., Cinnirella S., Magnani F., Impact of long term drought on xylem embolism and growth in Pinus halepensis Mill., Trees 12 (1998) 187-195.

[3] Brodribb T., Hill R.S., The importance of xylem constraints in the distribution of conifer species, New Phytol. 143 (1999) 365-372.

[4] Cochard H., Vulnerability of several conifers to air embolism, Tree Physiol. 11 (1992) 73-83. 
[5] Engelbrecht B., Velez V., Tyree M.T., Hydraulic conductance of two co-occuring neotropical understory shrubs with different habitat preferences, Ann. For. Sci. 57 (2000) 201-208.

[6] Grunwald C., Schiller G., Needle xylem water potential and water saturation deficit in provenances of Pinus halepensis Mill. and Pinus brutia Ten., For. méditerr. 10 (1988) 407-414.

[7] Hargrave K.R., Kolb K.J., Ewers F.W., Davis S.D., Conduit diameter and drought-induced embolism in Salvia mellifera Greene (Labiatae), New Phytol. 126 (1994) 695-705.

[8] Jarbeau A., Ewers F.W., Davis S.D., The mechanism of water-stress-induced embolism in two species of chaparral shrubs, Plant Cell Environ. 18 (1995) 189-196.

[9] Kavanagh K.L., Bond B.J., Aitken S.N., Gartner B.L., Knowe S., Shoot and root vulnerability to xylem cavitation in four populations of Douglas-fir seedlings, Tree Physiol. 19 (1999) 31-37.

[10] Kolb K.J., Sperry J.S., Differences in drought adaptation between subspecies of sagebrush (Artemisia tridentata), Ecology 80 (1999) 2373-2384.

[11] Lemoine D., Peltier J.P., Marigo G., Comparative studies of the water relations and the hydraulic characteristics in Fraxinus excelsior, Acer pseudoplatanus and A. opalus trees under soil water contrasted conditions, Ann. For. Sci. 58 (2001) 723-731.

[12] Linton M.J., Sperry J.S., Williams D.G., Limits to water transport in Juniperus osteosperma and Pinus edulis: implications for drought tolerance and regulation of transpiration, Funct. Ecology 42 (1998) 317-380

[13] Maherali H., DeLucia E.H., Xylem conductivity and vulnerability to cavitation of ponderosa pine growing in contrasting climate, Tree Physiol. 20 (2000) 859-867.

[14] Pammenter N.W., Vander Willingen C., A mathematical and statistical analysis of the curves illustrating vulnerability of xylem cavitation, Tree Physiol. 18 (1998) 589-593.

[15] Petty J.A., Puritch G.S., The effects of drying on the structure and permeability of the wood of Abies grandis, Wood Sci. Technol. 4 (1970) 140-154.

[16] Piñol J., Sala A., Ecological implications of xylem cavitation for several Pinaceae in the Pacific Northern USA, Funct. Ecology 14 (2000) 538-545.

[17] Pockman W.T., Sperry J.S., Vulnerability to xylem cavitation and the distribution of Sonoran desert vegetation, Amer. J. Bot. 87 (2000) 1287-1299.

[18] Salleo S., LoGullo M.A., Drought resistance strategies and vulnerability to cavitation of some Mediterranean sclero- phyllous trees, in: Borghetti M., Grace J., Raschi A. (Eds.), Water transport in plant under climatic stress, Cambridge University Press, Cambridge, 1993, pp. 99-113.

[19] Siau J.F., Transport processes in wood, Springer-Verlag, Berlin, 1984.

[20] Sparks J.P., Black R.A., Regulation of water loss in populations of Populus trichocarpa: the role of stomatal control in preventing xylem cavitation, Tree Physiol. 19 (1999) 453-459.

[21] Sperry J.S., Ikeda T., Xylem cavitation in roots and stems of Douglas-fir and white fir, Tree Physiol. 17 (1997) 275-280.

[22] Sperry J.S., Saliendra N.Z., Intra- and inter-plant variation in xylem cavitation in Betula occidentalis, Plant Cell Environ. 17 (1994) 1233-1241.

[23] Sperry J.S., Tyree M.T., Mechanism of water stressinduced xylem embolism, Plant Physiol. 88 (1988) 581-587.

[24] Sperry J.S., Tyree M.T., Water-stress-induced xylem embolism in three species of conifers, Plant Cell Environ. 13 (1990) 427-436.

[25] Sperry J.S., Nichols K.L., Sullivan J.E.M., Eastlack S.E., Xylem embolism in ring-porous, diffuse-porous and coniferous trees of northern Utah and interior Alaska, Ecology 75 (1994) 1736-1752.

[26] Tognetti R., Longobucco A., Raschi A., Vulnerability of xylem to embolism in relation to plant hydraulic resistance in Quercus pubescens and Quercus ilex co-occuring in a Mediterranean coppice stand in central Italy, New Phytol. 139 (1998) 437-447.

[27] Tognetti R., Michelozzi M., Giovannelli A., Geographical variation in water relations, hydraulic architecture and terpene composition of Aleppo pine seedlings from Italian provenances, Tree Physiol. 17 (1997) 241-250.

[28] Tyree M.T., Ewers F.W., The hydraulic architecture of trees and others woody plants, New Phytol. 119 (1991) 345-360.

[29] Tyree M.T., Ewers F.W., Hydraulic architecture of woody tropical plants, in: Mulkey S.S., Chazdon R.L., Smith A.P. (Eds.), Tropical Forest Plant Ecophysiology, Chapman et Hall, 1996, pp. 218-241.

[30] Tyree M.T., Davis S.D., Cochard H., Biophysical perspectives of xylem evolution: is there a tradeoff hydraulic efficiency for vulnerability to dysfunction, IAWA Journal 15 (1994) $335-360$.

[31] Zimmermann M.H., Xylem structure and the ascent of sap, Springer-Verlag, Berlin, 1983. 